\title{
CHARACTERISTICS OF MEAT PRODUCTIIVITY IN CHUB, Squalius cephalus (L., 1758) FROM UPPER AKCAY RIVER, BUYUK MENDERES BASIN (TURKEY)
}

\author{
Hüseyin ŞAŞI* \\ Fisheries Faculty, Mugla Sitki Kocman University, Turkey, hsasi@mu.edu.tr \\ (iD https://orcid.org/0000-0003-2734-3671 \\ Mohammed SAIDU, \\ Fisheries Faculty, Mugla Sitki Kocman University, Turkey, gidagida21@gmail.com \\ (iD) https://orcid.org/0000-0001-7338-2693
}

Received: 26.10.2017, Accepted: 16.05.2018

Research Article

*Corresponding author DOI: $10.22531 /$ muglajsci.346772

\begin{abstract}
The meat productivity of chub (Squalius cephalus) and the relationship between various organs of the body were determine after catching 153 fish samples from upper Akcay River, South Aegean Region between June 2012 and May 2013. In this study, the following results are obtained; percentage of head weight $16.00 \%$, visceral weight $9.90 \%$, fins weigh $6.30 \%$ and Meat productivity 67.10\%. Depending on their age between I and VII, chub population meat efficiency percent was determined as 64.44; 66.86; 70.63; 71.73; 71.31; 71.01 and 67.60 respectively. These results show that meat production increased as the age increases. It was later proposed to catch fish that have reach maturity age and are larger than 16,20cm length. Results showed that meat productivity of fish was increased after age $V$. in this river.

Keywords: Squalius cephalus, Chub, Meat productivity, body ratio, Akcay River, Mugla

\section{BÜYÜK MENDERES HAVZASI AKÇAY'IN ÜST KISMINDAKİ TATLISU KEFALİ, Squalius cephalus (L., 1758) ET VERIMLİLİĞì ÖZELLİKLERİ (TÜRKIYYE)}

$\ddot{0} \mathbf{z}$

Bu çalışmada Güney Ege Bölgesi'nde Büyük Menderes havzasındaki Akçay'ın üst kısımlarından yakalanan 153 adet tatlısu kefali (Squalius cephalus)'nin et verimliliği ile çeşitli vücut organları arasındaki ilişkiler incelenmiştir. Bu tür yörede ekonomik öneme sahiptir. Yapılan araştırma sonucunda, yüzdelik olarak ortalama baş ağırlığı oranı \%16.00; iç organların ağırlığı \%9.90; yüzgeç ağırlığ \%6.30 ve et randımanı \%67.10 olarak bulunmuştur. Tatlısu kefali populasyonunun I-VII yaşları arasındaki et verimliliği, yüzde olarak sırasıyla 64.44; 66.86; 70.63; 71.73; 71.31; 71.01 ve 67.60 olarak belirlenmiştir. Buna göre, yaş arttıkça et randımanın da arttığı görülmektedir. Balıkların eșeysel olgunluğa eriştikten sonra 16.20 cm'ye ulaştıktan sonra yakalanması önerilebilir. Çalışma sonuçları bu nehirde yakalanan balıkların et verimliliğinin V. yaşından sonra arttığını göstermiștir.

Anahtar Kelimeler: Squalius cephalus, Tatlısu kefali, Et verimliliği, Vücut oranları, Akcay, Muğla

Cite

Şaşı, H., Saidu, M., (2018). “Characteristics of meat productivity in chub, Squalius Cephalus (l., 1758) from upper Akcay river, Büyük Menderes basin (Turkey)", Mugla Journal of Science and Technology, 4(1), 1-5.

\section{Introduction}

The chub, Squalius cephalus (L., 1758) is distributed Turkey wide in inland waters (Lakes and rivers). From the South Aegean region; S. cephalus is a native fish species from Akcay River (Buyuk Menderes Basin) that is locally consume [1].

Chub (Squalius cephalus) is among the Cyprinidae family and also one of the most common species in Anatolian freshwater. Squalius cephalus (Linneaus, 1758) can be found in Europe, Black Sea, and Caspian Sea basin. Chub is benthopelagic and potamodromous [2].

Squalius cephalus is dominant with other native species, Acathobrama mirabilis in the upper Akcay River [3]. The chub populations are abundant in running water like Lakes, Barbel zone, riffles, pools and dams $[1,4,5]$, because the species have high ecological tolerance [2].
Some bio-ecological characteristics of various chub populations was studied in some areas of Turkey [6-11] and Europe [1214].

Chub meat productivity is economically important for the benefit of the people in the region. There are more marketing opportunities when compared with other species. Few spikelet's, meaty fish are more commonly held in markets due to high meat efficiency and quality. The price of fish is determined according to the species. There is an extra charge for cattle and sheep meat if it's above $50 \%[15,16]$.

From other studies conducted on meat productivity; Celikkale [17] compared the total body weight of various organs in cultured carp with that of other agricultural animals, Ozdemir [18]. Tigris scraper, Capoeta capoeta umbla (Heckel, 1843) in Elazig-Hazar Lake, meat productivity, Ozdemir and Temizer [16], carp, Cyprinus carpio in Cıldır Lake, Sasi [19], chub, 
Squalius cephalus and Sasi [20], bergama barb, Capoeta bergamae in Topcam Dam Lake.

Chub has an economic important to the local people in the region. This study concentrates more on meat productivity and its characteristics. The relationship between head, internal organ, fin weight, carcass weight and body weight of Squalius cephalus were calculated in other to know the meat productivity of the species.

\section{Materials and Method}

The study was carried out in upper Akcay River from 3 different districts (Esencay, Goktepe, Camoluk) of Aydin and Mugla provinces (Figure 1). Samples were collected monthly between June, 2012 and May, 2013 by the use of seine net and electrofishing. The nets and electro-shocker were randomly sampled leaving the various parts of the River suitable for fishery. The 153 fish Samples were group according to their ages; I. age 15, II age 44, III. age 38, IV. age 27, V. age 18, IV. age 7 and VII. age 4 individual.

The fish samples retrieved from the river were reserved under $4-5 \%$ formalin solution in cold room. The samples were measured using fork length $(\mathrm{cm}, \mathrm{LF})$ with a $0.1 \mathrm{~mm}$ precision ruler. Total body, head, internal organ and fin weights were measured with electronic scales with a sensitivity of $0.01 \mathrm{~g}$. The caudal, dorsal, ventral, pectoral, anal fins and head region are carefully cut with a sharp lancet. The internal organs were removed by opening the abdomen and chest of the fish. Age prediction was determined by microscopic examination of scales, which were collected above the lateral line of the fish [21].

For meat efficiency, head, internal organs and fins weight were weigh individually and proportionally to total weight [15].

Fork size (LF): The fork size of each fish was determined on a 1 mm precision measuring bench.

Body weight (WT): Indicates the total weight of the fish. Each individual's weight was recorded by weighing with a precision scale of $0.01 \mathrm{~g}$.

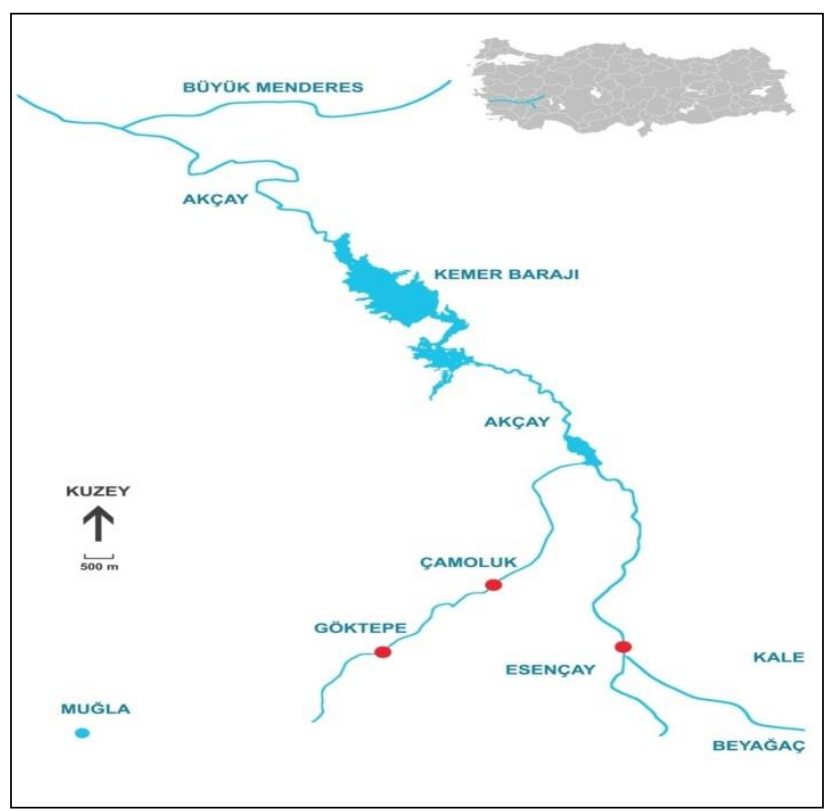

Figure 1. Study area in Upper Akcay River.

Head weight (HeadW): The head's operculum were cut with a sharp lancet and measured on a precision scales with a scale of 0,01 .
Internal organs weight (VisW): The samples were measured on a precision scales with a sensitivity scale of 0,01 after the abdominal and chest regions is opened and internal organs are extracted.

Fin weight (FinW): Pectoral, ventral, dorsal, anal and caudal fins were cut with a sharp blade and the weight of all fins was determined with a scale of $0.01 \mathrm{gr}$.

Carcass weight (CaW): The internal organs (together with gonads), head, fins and the remaining part were evaluated in calculating meat yield.

Meat Yield (\%), from total body weight, head, internal organ and fins weight were first removed before measuring carcass.

It is benefited by the fact that it is practically and sufficiently healthy at the age of determination [22]. From this study the mean values (Avg.) and standard deviation (SD) obtained are given

\section{Results}

\subsection{Meat Efficiency}

S. cephalus population determines the meat productivity of carcass weight. The head and fins of the fish were cut, the internal organs removed and the weight ratio of every part was calculated (Table 1).

The mean percentage weights of $S$. cephalus population, without separating from the bones are found to be carcass weight $67.10 \%$. Internal organ weight $9.90 \%$, Head weight $16.00 \%$ and fin weight $6.30 \%$.

Table 1. Meat productivity in S. cephalus population from upper Akcay River.

\begin{tabular}{|l|l|l|l|}
\hline Body part & Min. & Max. & Avg..SD \\
\hline Total weight (WT, g) & 4.60 & 109,70 & $56,80 \pm 74.80$ \\
\hline $\begin{array}{l}\text { Head weight } \\
\text { (HeadW, g) }\end{array}$ & 0.70 & 15.40 & $8.10 \pm 10.40$ \\
\hline $\begin{array}{l}\text { Visceral weight } \\
\text { (VisW, g) }\end{array}$ & 0.70 & 10.00 & $5.20 \pm 6.80$ \\
\hline $\begin{array}{l}\text { Fin weight } \\
\text { (FinW, g) }\end{array}$ & 0.20 & 6.80 & $3.50 \pm 4.60$ \\
\hline $\begin{array}{l}\text { Carcass weight } \\
\text { (CaW, g) }\end{array}$ & 2.60 & 76.60 & $39.60 \pm 52.40$ \\
\hline HeadW./ WT (\%) & 14.00 & 17.90 & $16.00 \pm 2.80$ \\
\hline VisW./ WT (\%) & 9.10 & 10.60 & $9.90 \pm 1.10$ \\
\hline FinW / WT (\%) & 4.50 & 6.50 & $6.30 \pm 0.10$ \\
\hline CaW / WT (\%) & 56.00 & 69.80 & $67.10 \pm 3.80$ \\
\hline
\end{tabular}

\subsection{Some Organ Weights and Length of Age}

According to age characteristic, the fish samples were characterized in accordance to minimum, maximum, average values of body size, head, internal organ and fin weights in grams (g) and fork length of Squalius cephalus in upper Akcay River (Table 2).

the I-VII age groups of $S$ cephalus average values changed in lengths 7,25-20,10 cm, body weights 7,35-98,03 g, head weights $1,13-13,69 \mathrm{~g}$, internal weights $0,81-8,76$, fin weights 0.47-6.06 and carcass weights $4.73-66.27 \mathrm{~g}$. respectively. 
Table 2. Meat productivity in S. cephalus population from upper Akcay River.

\begin{tabular}{|c|c|c|c|c|c|c|c|}
\hline Age & $\mathbf{N}$ & $\begin{array}{c}\mathbf{L F} \pm \mathbf{S D} \\
(\min -\mathbf{m a x}) \\
(\mathbf{c m})\end{array}$ & $\begin{array}{l}\text { WT } \pm \text { SD } \\
(\text { min-max }) \\
(g)\end{array}$ & $\begin{array}{c}\text { HeadW } \pm \text { SD } \\
\text { (min-max.) } \\
(\text { g) }\end{array}$ & $\begin{array}{c}\text { ViscW } \pm \text { SD } \\
(\text { min-max.) } \\
(\mathrm{g})\end{array}$ & $\begin{array}{c}\text { FinW } \pm \text { SD } \\
(\min -\max ) \\
(\mathrm{g})\end{array}$ & $\begin{array}{c}\mathrm{CaW} \pm \mathrm{SD} \\
(\mathrm{min}-\mathrm{Sax} .) \\
(\mathrm{g})\end{array}$ \\
\hline \multirow[t]{2}{*}{ I } & 15 & $7.25 \pm 0.803$ & $7.35 \pm 2.397$ & $1.13 \pm 0.299$ & $0.81 \pm 0.225$ & $0.47 \pm 0.160$ & $4.73 \pm 0.059$ \\
\hline & & $(6.1-8.6)$ & $(3.96-10.46)$ & $(0.71-1.60)$ & $(0.42-1.30)$ & $(0.21-0.78)$ & $(2.55-7.40)$ \\
\hline \multirow[t]{2}{*}{ II } & 44 & $10.04 \pm 0.574$ & $16.50 \pm 7.517$ & $2.54 \pm 0.707$ & $1.62 \pm 0.707$ & $1.01 \pm 0.537$ & $11.03 \pm 0.606$ \\
\hline & & $(9.1-11.2)$ & $(10 . .87-21.90)$ & $(1.80-3.06)$ & $(0.70-2.56)$ & $(0.52-1.51)$ & $(6.59-15.50)$ \\
\hline \multirow[t]{2}{*}{ III } & 38 & $12.1 \pm 0.530$ & $27.37 \pm 3.530$ & $3.62 \pm 0.589$ & $2.45 \pm 0.327$ & $1.53 \pm 0.249$ & $19.33 \pm 2.216$ \\
\hline & & $(11.2-13.0)$ & $(20.92-34.70)$ & $(2.65-4.84)$ & $(1.87-3.16)$ & $(1.00-2.10)$ & $(14.48-24.28)$ \\
\hline \multirow[t]{2}{*}{ IV } & 27 & $14.1 \pm 0.743$ & $44.55 \pm 7.835$ & $6.32 \pm 1.115$ & $3.34 \pm 0.619$ & $2.27 \pm 0.442$ & $31.95 \pm 6.376$ \\
\hline & & $(12.8-15.4)$ & $(33.58-63.82)$ & $(4.45-8.30)$ & $(2.22-3.34)$ & $(1.53-3.91)$ & $(23.93-45.10)$ \\
\hline \multirow[t]{2}{*}{$\mathbf{V}$} & 18 & $16.21 \pm 0.738$ & $63.31 \pm 6.425$ & $8.92 \pm 0.648$ & $4.83 \pm 0.616$ & $3.48 \pm 0.382$ & $45.15 \pm 7.796$ \\
\hline & & $(15.3-17.9)$ & $(53.20-75.38)$ & $(7.90-10.00)$ & $(3.46-6.27)$ & $(2.82-4.10)$ & $(36.33-53.91)$ \\
\hline \multirow[t]{2}{*}{ VI } & 7 & $18.27 \pm 0.364$ & $79.99 \pm 4.101$ & $10.66 \pm 1.328$ & $6.60 \pm 0.627$ & $4.68 \pm 0.239$ & $56.81 \pm 2.044$ \\
\hline & & $(17.9-19.0)$ & $(74.60-85.90)$ & $(9.50-12.90)$ & $(5.65-7.36)$ & $(4.38-5.10)$ & $(53.35-60.86)$ \\
\hline \multirow[t]{2}{*}{ VII } & 4 & $20.10 \pm 0.493$ & $98.03 \pm 8.899$ & $13.69 \pm 1.420$ & $8.76 \pm 0.875$ & $6.06 \pm 0.522$ & $66.27 \pm 0.493$ \\
\hline & & $(19.5-20.6)$ & $(88.14-109.7)$ & $(12.13-15.4)$ & $(8.00-10.00)$ & $(5.61-6.80)$ & $(61.29-70.39)$ \\
\hline
\end{tabular}

\subsection{Ratio of Organs to Body Weight and Meat Yield}

The percentage ratios (\%) of the various organ weights and meat yield capacity of chub to body weight are given in Table 3 . The fish samples show differences according to their age groups. Head weight ratios $13.23-15.42 \%$, internal weight ratios $7.49-10.99 \%$, fin weight ratios $5.10-6.37 \%$, and meat efficiency $64.44-71.73 \%$ (Table 3 and Fig 2 ).

Table 3. The percentage of age groups of S. cephalus meat efficiency from organs of body weight (\%).

\begin{tabular}{|l|c|c|c|c|c|}
\hline Ages & $\mathrm{N}$ & $\begin{array}{c}\text { HeadW } \\
(\%)\end{array}$ & $\begin{array}{c}\text { VisW } \\
(\%)\end{array}$ & $\begin{array}{c}\text { FinW } \\
(\%)\end{array}$ & $\begin{array}{c}\text { CaW } \\
(\%)\end{array}$ \\
\hline I & 15 & 15.41 & 10.99 & 6.37 & 64,44 \\
\hline II & 44 & 15.42 & 9.82 & 6.14 & 66,86 \\
\hline III & 38 & 13,23 & 8.97 & 5.60 & 70,63 \\
\hline IV & 27 & 14.19 & 7.49 & 5.10 & 71,73 \\
\hline V & 18 & 14.09 & 7.63 & 5.50 & 71,31 \\
\hline VI & 7 & 13.32 & 8.25 & 5.85 & 71,01 \\
\hline VII & 4 & 13.97 & 8.94 & 6.18 & 67,6 \\
\hline
\end{tabular}

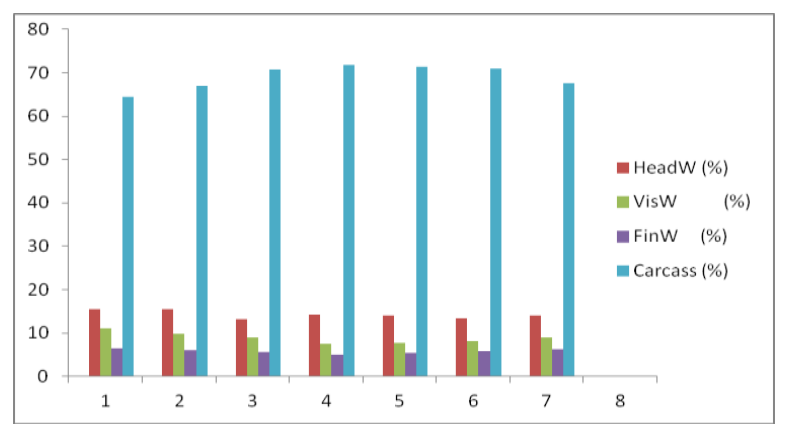

Figure 2. The percentage of body weight of S. cephalus, relations between various organs and meat efficiency (\%).

\section{Discussion and Conclusion}

The age distribution of $S$. cephalus population from upper Akcay River change between I and VII.
Part of the fish that can be evaluated is described as the total ratio of meat supply [15], [23]. The fish size change according to species, fishing season and nutrition. During breeding season, the female's gonads increase in number but the meat capacity decrease, after extracting the head, internal organs and fins, $70 \%$ of the meat remains.

Akcay River is located in southwestern Turkey; the basin is under temperate climate. Cyprinid species develop healthy in water with a biological characteristic of $20^{\circ} \mathrm{C}$.

The average meat yield of the examined species is around $67.10 \%$, head weight at $16.00 \%$, internal organ weight at $9.90 \%$ and fin weight at $6.30 \%$. Aras et al. [24] mentioned that the average performance of carcass weight, head weight, internal organ weight and fin weight were found to be $61.44 \%, 22.32 \%, 12.78 \%$ and $1.51 \%$, respectively, from the study conducted on C. capoeta umbla (Heckel, 1843) population in Karasu River. The ratios were found to be different to each other. Celikkale [17] found a meat yield of $56.50 \%$ in a study conducted on cultural carp, C. carpio. Mirror carp grown in cultural conditions in the Aegean Region, meat yield was determined as $58.40 \%$ and in wild carp as $66.30 \%$ [25]. Sasi [19] reported that the meat yield of chub (Leuciscus cephalus L., 1758) in Topcam Dam Lake to be $62.73 \%$.

Ozdemir and Temizer [16] reported that the average meat yield of carp was $61.53 \%$, head weight $17.56 \%$, internal organ weight $15.85 \%$ and the fin weight $3.76 \%$ in C1ldır Lake. This shows the values of meat yield and head weight. This result is close to the report we obtained.

The organs weight and body weight increased according to age (Table 2, Figure 2). At I. age meat weight was $4.73 \mathrm{~g}$ and at VII. age meat weight was $66.27 \mathrm{~g}$.

S. cephalus meat yield ratios were $64.44 \%$ low at I. age while in IV. age the ratio was $\% 71,73$ high. This appears to be the highest value of age that was determined. Ikiz et al. [26] found that the meat yield of ell (A. anguilla L., 1758) in the Aksu Stream varied between $69.04 \%$ and $71.85 \%$.

The rate of meat productivity is higher than $70 \%$ in fish with small head and internal organs such as trout (Salmonidae), tuna (Thunnus thynnus), and ell (Anguilla anguilla). In fishes with large head and stomach contents, such as whiting (Merlangius merlangus) and carp (Cyprinus carpio), meat yield is less than 70\% [15]. 
The population of $S$. cephalus, is abundant in South Aegean region. It was found to grow up to $109.70 \mathrm{~g}$ weight and $20.10 \mathrm{~cm}$ in the study area. While the mean weight of $27.37 \mathrm{~g}$ and the mean weight of carcass $(19.33 \mathrm{~g}$ ) was found at III. age, at age IV the weights reached $44.55 \mathrm{~g}$ with average weights of $31.95 \mathrm{~g}$ respectively. They could grow up to $308.80 \mathrm{~g}$ weight and $26.00 \mathrm{~cm}$ in Topcam Dam Lake [20].

In previous study, it was suggested that the chub population in the region reached its sexual maturity between age III and IV. It has been proposed to catch fish longer than $16,20 \mathrm{~cm}$ in height after reaching maturity age. In addition, the exploitation rate of this population is found $45 \%$ by Sasi and Ozay [3].

The river is suitable for the development of chub population and meat productivity, but meat productivity is less than lentic habitats. In this River implementation of V. age fish will increase meat productivity. It would be appropriate to use this method more economically.

\section{Acknowledgment}

The authors wish to thank the Mugla Sitki Kocman University Research Fund (BAP-12/88) supporting the study. Also, Thanks to Mr. Recai Genc to help in field collecting fish samples.

\section{References}

[1] Geldiay, R. and Balık, S., Türkiye Tatlısu Balıkları, Ege Üniv. Su Ürünleri Fak. Yayın No: 46, II. Baskı, İzmir, 532 p., 1996.

[2] Kottelat, M. and Freyhof, J., Handbook of European Freshwater Fishes, The World Conservation Union (IUCN), Switzerland, 646 p., 2007.

[3] Sasi, H., and Ozay, S., "Investigation of Bio-Ecological Characteristics of European chub (Squalius cephalus L., 1758) in Akcay River", Mugla Sitki Kocman University, BAP Project 12/88, Mugla, 100 p., 2014.

[4] Slastenenko, E., "Fish Fauna in Black Sea Basin", Et ve Balık Kurumu Umum Müdürlüğü Yayınları, Ankara, 711 p., 1956.

[5] Sasi, H. and Balık, S., "Age, growth and sex ratio of chub (Leuciscus cephalus L., 1758) in Topçam Dam Lake (Aydın, Turkey)", Ege Journal of Fisheries and Aquatic Sciences, 20, 503-515, 2003.

[6] Unlu, E. and Balci, K., "Savur Cayı'nda Yaşayan Bazı Cyprinidae (Pisces) Eşeysel Olgunluk Yașı, Yumurtlama Dönemi ve Yumurta Verimi Uzerine Bir Araştırma", Ege Univ. Egitiminin 10. Yilinda Su Urunleri Sempozyumu, Izmir, pp. 347-356, 1991.

[7] Yerli, S.V., Calışkan, M. and Canbolat, A.F., "Cıldır Gölü (Ardahan)'ndeki Leuciscus cephalus'un büyüme ölçütleri üzerine incelemeler", Turkish Journal of Zoology, 23, 271 278, 1999.

[8] Kalkan, E., Yilmaz, M. and Erdemli, A.U., (2005). Some biological properties of the Leuciscus cephalus (L., 1758) population living in Karakaya Dam Lake in Malatya (Turkey). Turkish Journal of Veterinary and Animal Science, 29, 49-58.

[9] Koc, H.T., Erdogan, Z., Tinkci, M. and Treer, T., "Age, growth and reproductive characteristics of chub, Leuciscus cephalus (L., 1758) in the İkizcetepeler Dam Lake (Balıkesir), Turkey", Journal of Applied Ichthyology, 23, 19-24, 2007.

[10] Bostancl, D. and Polat, N., (2009). Age Determination and Some Population Characteristics of Chub (Squalius cephalus L., 1758) in the Camlıdere Dam Lake (Ankara, Turkey). Turkish Journal of Science \& Technology, 4,1, 2530.

[11] Innal, D., "Population Structures and Some Growth Properties of Three Cyprinid Species [Squalius cephalus
(Linnaeus, 1758); Tinca tinca (Linnaeus, 1758) and Alburnus escherichii Steindachner, 1897] Living in Camkoru Pond (Ankara-Turkey", Kafkas Univ Vet Fak Der.,16 (Suppl-B), 297-304, 2010.

[12] Treer, T., Habekovic, D., Safner, R., Kolak, A. and Anicic, I., "Length-mass relationship in chub (Leuciscus cephalus) from five Croatian Rivers", Agriculturae Conspectus Scientificus, 64, 137-142, 1999.

[13] Markovic, G., Simic, V., Ostojic, A. and Simic, S., "The diet of Leuciscus cephalus L. in the reservoir Medjuvrsje (Western Morava, Serbia)", Acta Agriculturae Serbica, 8, 75-81, 2003.

[14] Raikova-Petrova, G., Hamwi, N. and Petrov, I., "Spawning, Sex Ratio and Relationship between Fecundity, Length, Weight and Age of Chub (Squalius cephalus L., 1758) in the Middle Stream of Iskar River (Bulgaria)", Acta Zool. Bulg., 64,2, 191-197, 2012.

[15] Anıl, N., Nizamoğlu, M. ve Doğruer, Y., "Balıklarda Grading Sisteminin Geliștirilmesi ve Kalite Kontrolünün Tespiti Üzerinde Çalıșmaları", S. Ü. Vet. Fak. Derg. 4 (1), 238-249, 1989.

[16] Ozdemir, N. ve Temizer, A., “Çıldır Gölünde Yaşayan Sazanların (Cyprinus carpio L. 1758) Et Verimi İle İlgili Bir Araștırma", Fırat Üniv. XI. Ulusal Biyoloji Kongresi, Elazığ, pp. 175-178, 1992.

[17] Celikkale, M. S., Kültür Sazanlarında çeşitli organların toplam vücut ağırlığındaki oranları, yenilebilir kısmın miktarı ve diğer ekonomik içsu balıkları ve tarım hayvanları ile karşılaştırılması, TÜBİTAK IV. Bilim Kong. Veteriner ve Hay. Araşt. Grub. Teb., Tübitak Yayın No: 389, V.H.A.G. Seri No: 10, Ankara, 1978.

[18] Ozdemir, N., "Elazığ-Hazar Gölü'nde Yaşayan Capoeta capoeta umbla (Heckel, 1843)'nın Et Verimi İle İlgili Özellikleri", E. Ü. Faculty of Science Journal Series B, Suppl., 2, 149-161, 1983

[19] Sasi, H., "Güney Ege Bölgesi'ndeki Tatlısu Kefalinin (Leuciscus cephalus L. 1758) Et Verimi İle İlgili Özellikler", Istanbul Üniv., Su Ürünleri Dergisi, 17, 1-7, 2004.

[20] Sasi, H., “Güney Ege Bölgesi'ndeki Topcam Baraj Gölü’nde Yaşayan Siraz Balığının (Capoeta bergamae Karaman, 1969) Et Veriminin Belirlenmesi”, Ege Üniv., Su Ürünleri Dergisi, 26,1, 35-38, 2009.

[21] Lagler, K.F., Freshwater Fishery Biology. W.M.C. Brown Company, Iowa, USA, 1956.

[22] Ekingen, G. ve Polat, N., "Age Determination and LengthWeigth Relations of Capoeta capoeta umbla (Heckel) in Lake Keban", Doğa Tr. J. of Zooloji Der., 11,1 : 5-15, 1987.

[23] Gulyavuz, H. ve Altınkurt, A., Besin Issleme Teknolojisi. M.E.B. Basımevi, İstanbul, 320 p., 1991.

[24] Aras, S., Yanar, M. and Bircan, R., Karasu Irmağı'nda Yaşayan Capoeta capoeta umbla (Heckel,1843)'nin Et Verimi ile Çeşitli Vücut Organları Arasındaki İlişkiler, Atatürk üniversitesi, Ziraat Fak., Erzurum, pp. 106-115, 1992.

[25] Alpbaz, A. G. ve Hoşsucu, H., “Gölmarmara Sazanı (Cyprinus carpio L.) ve Aynalı Sazan (Cyprinus carpio L. var: Royal)'ın Ege Bölgesi Kültür Koşullarında Verim Özellikleri Üzerinde Araștırmalar", Doğa Bil. Der., Seri: D, 4 (3), 1980.

[26] Ikiz, R., Gülyavuz, H. ve Küçük, F., Aksu Çayı'ndaki Yılan Balıklarının (Anguilla anguilla L., 1758) Etlerinin Kimyasal Yapısı Üzerine Bir Araştırma, Tr. J. of Zoology, 171-175, 1994. 